\title{
KLAIPĖDOS MIESTO GYVENTOJŲ GYVENSENA: FIZINIO AKTYVUMO YPATUMAI
}

\author{
Birutė Strukčinskiene் ${ }^{1}$, Ineta Pačiauskaitė ${ }^{1}$, Sigitas Griškonis ${ }^{2,1}$, Vaiva Strukčinskaitė ${ }^{1}$, \\ Dalija Stasiuviené $\dot{e}^{1}$, Ieva Griškonyt $\dot{e}^{3}$ \\ ${ }^{1}$ Klaipédos universiteto Sveikatos mokslu fakultetas, ${ }^{2}$ Klaipédos universitetiné ligoniné, \\ ${ }^{3}$ Vilniaus universiteto Medicinos fakultetas
}

Raktažodžiai: sveikata, gyvensena, fizinis aktyvumas.

\section{Santrauka}

Sveika gyvensena, jos veiksniai, sąsajos su lètinèmis neinfekcinėmis ligomis yra vienos aktualiausių nūdienos visuomenès sveikatos temų. Darbo tikslas buvo analizuoti suaugusių Klaipėdos miesto gyventojų fizinio aktyvumo ypatumus. Tyrimo metu buvo apklausti 1062 Klaipèdos miesto savivaldybès gyventojai, vyresni nei 18 metų amžiaus (574 moterys ir 488 vyrai). Naudota kvotinè atranka ir tiesioginio interviu (angl. Face-to-face) metodas. Duomenų analizei naudotas SPSS 21.0 programų paketas, taikytas $\chi^{2}$ kriterijus. Statistinis hipotezių reikšmingumas patvirtintas, kai $p<0,05$.

Tyrimas parodè, kad apie pusę klaipédiečių (46,4 proc.) apie sveiką gyvenseną daugiausia žinių iggijo iš interneto. Per pastaruosius metus labai mažas skaičius (tik 7,3 proc.) gyventojų padidino savo fizinị aktyvumą dèl sveikatos. Dažniausiai klaipèdiečiai važinejja individualiu (48 proc.) ir viešuoju (43,5 proc.) transportu. Itin maža dalis gyventojų važiuoja dviračiu (1,3 proc. ) arba eina pesčiomis (6,8 proc.). Apie pusę klaipèdiečių ( 47,8 proc.) dirba mišrų (stovimą + sèdimą) darbą, trečdalis $(30,3$ proc.) - sédimą, penktadalis (20,5 proc.) - judamą darbą. Moterys daugiau dirba mišru (seddimą-stovimą) darbą, o vyrai - judrų ir sunkų fizini darbą. Maža Klaipėdos miesto savivaldybès gyventojų dalis reguliariai sportuoja. Tik 13,4 proc. respondentu laisvalaikiu mankštinasi bent keturias dienas per savaitę. Net 45,5 proc. gyventojų visai nesimankština. Tiek vyrai, tiek moterys mankštinasi nepakankamai. Trečdalis respondentų teigia, kad nesportuoja dèl laiko stokos. Beveik pusè klaipėdiečių sportuoja namuose. Moterys mieliau sportuoja namuose, o vyrai - sporto klube, sporto salejje arba stadione.

\section{Ivadas}

Sveika gyvensena, jos veiksniai, sąsajos su lètinėmis neinfekcinėmis ligomis yra vienos aktualiausių nūdienos visuomenès sveikatos temų. Sveikos gyvensenos sudètinès dalys, ypač pakankamas fizinis aktyvumas, sveika mityba, kova su žalingais ịpročiais, yra svarbūs veiksniai sveikatos stiprinimui ir lėtinių neinfekcinių ligų profilaktikai. Moksliniais tyrimais įrodyta, kad keičiant gyvensenos įpročius galima pagerinti gyventojų sveikatą ir pailginti jų gyvenimo trukmę, todèl sveikos gyvensenos ugdymui ir sąlygų sveikai gyventi sukūrimui skiriamas išskirtinis dèmesys [1]. Dél nesveikos gyvensenos ir negatyvios elgsenos, taip pat ir menko fizinio aktyvumo, didejja lètinių neinfekcinių ligu paplitimas. Be to, sveika elgsena bei sveika gyvensena yra ypač svarbūs gerai fizinei ir psichinei sveikatai [2]. Vienas svarbiausių šiuolaikinès kompiuterizuotos ir technizuotos visuomenès sveikatos rizikos veiksnių yra pasyvus gyvenimo būdas. Hipokinezija, fizinio aktyvumo, judejimo stoka, nepakankama aktyvios ir pasyvios veiklos kaita yra sveikatą silpninantys veiksniai [3-5]. Pastaruoju metu mokslininkai atkreipia dèmesi ị mažèjantị suaugusiųuu ir vaikų fizinị aktyvumą bei plintantị pasyvų gyvenimo būdą [6-8]. Technikos pažanga, urbanizacija, motorizacija sąlygoja suaugusiujų ir vaikų fizinio aktyvumo mažejimą [5]. Fiziniai pratimai, judejjimo aktyvumas, kūno kultūra padeda užtikrinti fizinę ir psichinę asmens darną [4-5]. Fizinis aktyvumas yra svarbus širdies ir kraujagyslių ligų, hipertonijos, insulto, vėžio, diabeto, osteoporozès profilaktikai, be to, fizine veikla ir sportas gerina fizinị ir protinị darbingumą, stiprina fizinę ir psichinę sveikatą $[3,4,6,9,10]$. Beje, fizinis aktyvumas stiprina ir imuninę sistemą [10]. Fizinis aktyvumas - viena iš pagrindinių žmogaus geros fizinès, socialinès ir emocinès būsenos sąlygų [11]. Taigi gyvensenos bei fizinio aktyvumo moksliniai tyrimai yra svarbūs visuomenès sveikatos stiprinimui, ligų profilaktikai ir gyventojų gerovei. 
Darbo tikslas - analizuoti suaugusių Klaipėdos miesto gyventojų fizinio aktyvumo ypatumus.

\section{Tyrimo metodika}

Klaipedos miesto populiacijos gyvensenos tyrimas buvo atliktas 2012 metais. Tyrimą koordinavo Klaipėdos miesto savivaldybès Visuomenès sveikatos biuras ir Klaipédos universiteto Sveikatos mokslų fakulteto Visuomenès sveikatos katedros mokslininkai. Tyrimo metu buvo apklausti 1062 Klaipėdos miesto savivaldybès gyventojai, vyresni nei 18 metų amžiaus (574 moterys ir 488 vyrai). Respondentai tyrimui buvo atrinkti naudojant kvotinę atranką, remiantis gyventojų pasiskirstymu pagal lytị ir amžių. Klaipedos miesto gyventojų kvotoms nustatyti buvo panaudoti 2011 metų Lietuvos statistikos departamento duomenys apie Klaipedos miesto gyventojų pasiskirstymą pagal lytį ir amžių. Vykdant gyventojų apklausą buvo naudojamas tiesioginio interviu (angl. face-to-face) metodas. Statistinei duomenų analizei naudotas SPSS 21.0 programų paketas. Tyrime taikytas $\chi^{2}$ kriterijus. Statistinis hipotezių

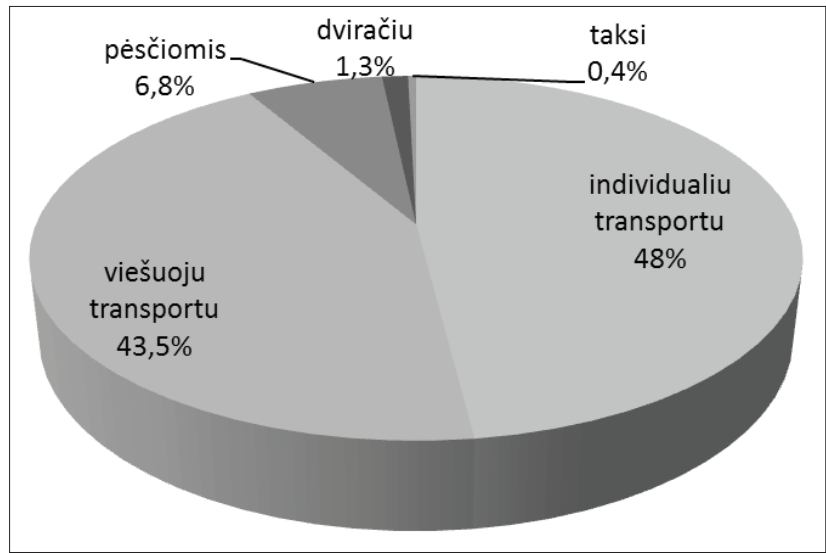

1 pav. Dažniausiai naudojama susisiekimo priemonè keliaujant Klaipėdos mieste

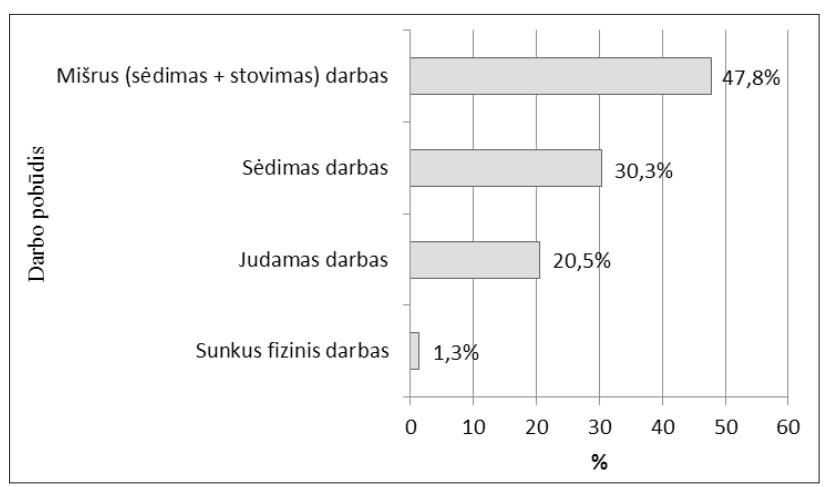

2 pav. Kasdienis darbas (kasdienè veikla) reikšmingumas patvirtintas, kai $\mathrm{p}<0,05$. Šiame straipsnyje aptarsime Klaipédos miesto gyventojų fizinio aktyvumo aspektus.

\section{Tyrimo rezultatai ir ju aptarimas}

Apklausos metu paaiškejjo, kad 493 (46,4 proc.) gyventojų pagrindinis informacijos šalinis apie sveiką gyvenseną yra internetas. Statistiškai reikšmingų skirtumų tarp vyrų ir moterų šiuo klausimu nebuvo ( $p>0,05)$. 11,9 proc. respondentų nurodé, kad sveikos gyvensenos žinių jie daugiausia igijo viešuosiuose renginiuose (paskaitose, seminaruose ir kt.), o 10,1 proc. apklaustujų nurodè, kad informacijos apie sveiką gyvenseną jie pasisėmè sveikatos mokymuose darbovieteje ar mokymo ịstaigoje. Per pastaruosius 12 mènesių fizini aktyvumą dèl sveikatos padidino tik 77 (7,3 proc.) gyventojų: 43 (7,5 proc.) moterys ir 34 (6,9 proc.) vyrai.

Tyrimo metu respondentų buvo klausiama, kokia transporto priemone, kokiu būdu dažniausiai keliauja miesto gyventojai. Tyrimų rezultatai parodè, kad beveik pusė (48 proc.) Klaipèdos miesto savivaldybès gyventojų važinėja individualiu transportu, t.y. nuosavu automobiliu. Panašus, tik nežymiai mažesnis skaičius gyventojų naudojasi vie-

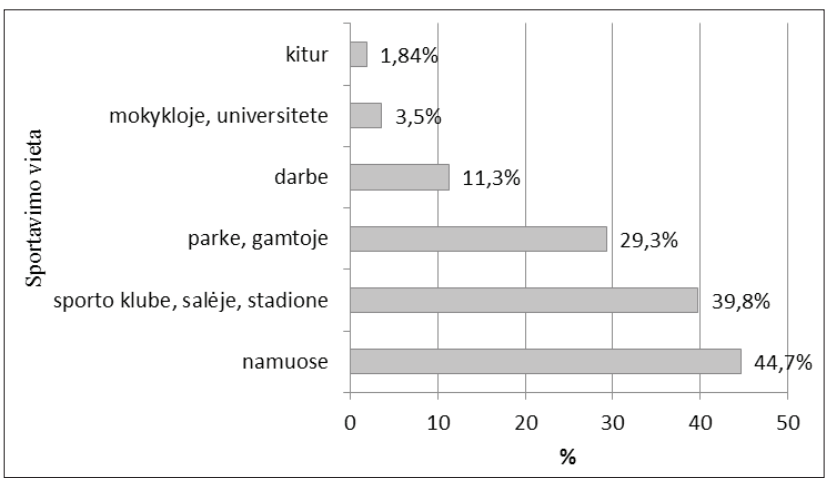

3 pav. Vieta, kur klaipėdiečiai sportuoja ar užsiima fizine veikla

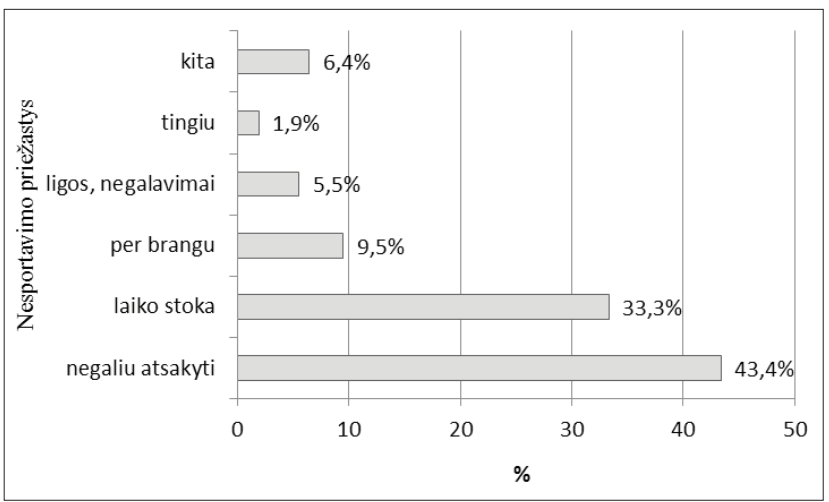

4 pav. Priežastys, kurios labiausiai trukdo reguliariai mankštintis 
šuoju transportu (43,5 proc.). Pėsčiomis Klaipėdoje vaikščioja tik 6,8 proc. gyventojų. Dviračiu, kaip pagrindine susisiekimo priemone, naudojasi labai mažai klaipeddiečiu -tik 1,3 proc.

Respondentų buvo paklausta, kiek fizinio aktyvumo reikalauja jų kasdienis darbas ar kita kasdienė veikla. Savo atsakymą jie galejjo pasirinkti iš 4 pateiktų atsakymų variantų:

- Daugiausia sėdimas darbas.

- Sedimas ir stovimas (mišrus) darbas, kai šiek tiek vaikštoma, kilnojama, nešiojama (pramonejje, prekyboje, lengva namų ruoša ir kt.).

- Judamas darbas, kai daug vaikštoma, kilnojama, nešiojama (pramoneje, statybose, sunki namų ruoša ir kt.).

- Sunkus fizinis darbas (žemès ūkyje, statybose, kelio darbai).

Beveik trečdalis Klaipėdos miesto savivaldybès gyventojų savo kasdieninį darbą ar veiklą ịvardijo kaip „,sėdimą darbą" (30,3 proc.), 47,8 proc. savo darbą ar veiklą apibūdino kaip „sèdimą ir stovimą darbą“, 20,5 proc. savo darbą ar veiklą apibūdino kaip ,judamą darbą" ir 1,3 proc. - kaip „sunkų fizinị darbąa" (2 pav.). Sėdimą darbą dirba panašus vyrų ir moterų skaičius. Mišrų (sėdimą-stovimą) darbą turi reikšmingai daugiau moterų $(55,8$ proc.), nei vyrų $(38,6$ proc.) ( $\mathrm{p}<0,05)$, o judamą $(30,3$ proc.) ir sunkų fizinị darbą $(2,4$ proc.) dirba daugiau vyrų nei moterų $(\mathrm{p}<0,05)$.

Klaipèdiečių buvo klausiama, kaip dažnai jie laisvalaikiu mankštinasi (sportuoja, bėgioja, važiuoja dviračiu, dirba sode ir pan.) mažiausiai $30 \mathrm{~min}$. taip, kad pagreitètų kvejpavimas ir asmuo suprakaituotų. Tyrimo metu paaiškejjo, kad Klaipèdos miesto gyventojų kasdienis fizinis aktyvumas yra menkas. Net 45,5 proc. gyventojų visai nesimankština. Apklausa atskleidè, kad kasdien mankštinasi tik 7,3 proc. respondentų, dar 6,1 proc. teigé sportuojantys 4-6 kartus per savaitę, 14,8 proc. - 2-3 kartus per savaitę, o 10 proc. mankštinasi kartą per savaitę. Skirtumų tarp lyčių pagal kasdienį fizini aktyvumą nenustatyta - tiek vyrai, tiek moterys mankštinasi nepakankamai.

Besimankštinančių respondentų buvo klausiama, kur jie sportuoja ir užsiima fizine veikla. Apklausiamieji galejo pasirinkti ir nurodyti keletą vietų, kur jie dažniausiai sportuoja (3 pav.). Namuose sportuoja apie pusę (44,7 proc.) fiziškai aktyvių klaipėdiečių. Sporto klube, sporto salejje ar stadione mankštinasi ir sportuoja 39,8 proc. respondentų. Parke ar gamtoje sportuoja 29,3 proc. respondentų. Nedidelè dalis aktyvių Klaipèdos miesto gyventojų sportuoja darbe arba ugdymo istaigoje (mokykloje, universitete). Moterys reikšmingai dažniau nei vyrai sportuoja namuose $(p<0,05)$. Vyrams labiau patinka sportine, fizine veikla užsiimti sporto saleje, sporto klube ar stadione.
Besimankštinančių respondentų buvo klausiama, kurios iš pateiktų priežasčių labiausiai trukdo reguliariai mankštintis, užsiimti sportine veikla. Trečdaliui Klaipedos miesto savivaldybės gyventojų dažniausia priežastis, kuri trukdo reguliariai mankštintis, yra laiko stoka (33,3 proc.). 9,5 proc. respondentų mano, kad jiems tai per brangu, o 5,5 proc. respondentų nesportuoja dèl ligos ir negalavimų (4 pav.). Apie trečdalis vyrų (33,8 proc.) ir moterų (33,0 proc.) nurodo, kad jiems trūksta laiko fiziniam aktyvumui ir sportavimui $(\mathrm{p}>0,05)$.

Tyrimas parodè, kad Klaipedos miesto gyventojai nepakankamai skiria dèmesio fiziniam aktyvumui, per mažai mankštinasi, mažai sportuoja. Tik 13,4 proc. respondentų laisvalaikiu mankštinasi bent keturias dienas per savaitę. Pagal 2012 metų „Suaugusių Lietuvos žmonių gyvensenos tyrimą" Lietuvoje bent 30 min. keturias ir daugiau dienų per savaitę laisvalaikiu mankštinasi 29 proc. suaugusiuju [1]. Be to, Lietuvoje penktadalis gyventojų eina pėsčiomis i darbą ir grį̌ta iš jo bent pusvalandi [1]. Tačiau tik apie 7 proc. klaipediečiu nurodo vaikščiojimą pėsčiomis kaip pagrindinę keliavimo priemonę.

Sveikatai stiprinti ir fiziniam aktyvumui skatinti Pasaulio sveikatos organizacija (PSO) parengè „Bendrąsias sveikatai skirto fizinio aktyvumo rekomendacijas“" [12]. PSO ekspertai rekomenduoja suaugusiems asmenims fizinei veiklai laisvalaikiu skirti bent po 30 minučių keturias dienas per savaitę, o vaikams fizinei veiklai ir sportavimui kasdien skirti po 60 minučių. PSO pabrèžia sveikatą gerinančio fizinio aktyvumo svarbą [13]. Sveikatos politikos formuotojai, visuomenès sveikatos specialistai, sveikatinimo veiklos organizatoriai ir vykdytojai pagrindinį demesį turetų skirti sveikatą stiprinančiam fiziniam aktyvumui, įtraukiant ị sportavimą ir judejjimą kuo daugiau visuomenès narių. Fizinè veikla, judesiai, fiziniai pratimai, sportavimas igalina stiprinti visuomenès sveikatą, leidžia išvengti susirgimų, streso, formuoti taisyklingą kaulų-raumenų sistemą, ugdyti profilaktinę žalingu ịpročių, traumatizmo veiklą, gerinti fizinę ir psichinę žmogaus sveikatą.

\section{Išvados}

1. Apie pusę klaipèdiečių (46,4 proc.) apie sveiką gyvenseną daugiausia žinių igijo iš interneto. Per pastaruosius metus labai mažas skaičius (tik 7,3 proc.) gyventojų padidino savo fizini aktyvumą dèl sveikatos.

2. Dažniausiai klaipèdiečiai važinèja individualiu (48 proc.) ir viešuoju ( 43,5 proc.) transportu. Itin maža dalis gyventojų važiuoja dviračiu (1,3 proc. ) arba eina pesčiomis $(6,8$ proc.).

3. Apie pusę klaipeddiečių (47,8 proc.) dirba mišrų (stovimą + sẻdimą) darbą, trečdalis (30,3 proc.) - sėdimą, 
penktadalis (20,5 proc.) - judamą darbą. Moterys daugiau dirba mišrų (sėdimą-stovimą) darbą, o vyrai - judrų ir sunkų fizinị darbą.

4. Maža Klaipèdos miesto savivaldybės gyventojų dalis reguliariai sportuoja. Tik 13,4 proc. respondentų laisvalaikiu mankštinasi bent keturias dienas per savaitę. Net 45,5 proc. gyventojų visai nesimankština. Tiek vyrai, tiek moterys mankštinasi nepakankamai. Trečdalis respondentų teigia, kad nesportuoja dèl laiko stokos.

5. Beveik pusė klaipėdiečiu sportuoja namuose. Moterys mieliau sportuoja namuose, o vyrai - sporto klube, sporto saleje arba stadione.

\section{Literatūra}

1. Grabauskas V., Klumbienė J., Petkevičienė J., Šakytė E., Kriaučionienè V., Veryga A. Suaugusių Lietuvos žmonių gyvensenos tyrimas, 2012. Kaunas: LSMU, 2013.

2. Yang ZY, Yang Z, Zhu L, Qiu C. Human behaviors determine health:strategic thoughts on the prevention of chronic noncommunicable diseases in China. Int J Behav Med 2011; 18(4): 295-301.

3. Skurvydas A. Judesių mokslas: raumenys valdymas, mokymas, reabilitavimas, sveikatinimas, treniravimas, metodologija. Kaunas: LKKA, 2008.

4. Strukčinskienė B., Raistenskis J., Šopagienė D., Kurlys D., Stasiuvienė D., Griškonis S., Radžiuvienė R. Vaikų fizinis aktyvumas ir sveikata. Klaipėda: S.Jokužio leidykla-spaustuvė, 2012.

5. Strukčinskienė B., Kurlys D., Griškonis S., Raistenskis J. Mokyklinio amžiaus vaikų sveikos gyvensenos ypatumai fazinio aktyvumo aspektu. Sveikatos mokslai, 2011; 21(7): 46-50.

6. Booth FW, Chakravarthy MV. Cost and consequences of sedentary living: New battleground for an old enemy. Research Digest 2002; 3(16): 1-6.

7. Allender S, Hutchinson L, Foster C. Life-change events and participation in physical activity: a systematic review. Health Promotion International 2008; 23(2): 160-172.

8. Strukčinskienė B., Griškonis S., Raistenskis J., Strukčinskaitė V. Ikimokyklinio amžiaus Lietuvos vaikų fizinio aktyvumo ypatumai. Sveikatos mokslai, 2012; 22(4): 10-14.

9. Mickevičienė D., Motiejūnaitė K., Skurvydas A. Fizinis aktyvumas ir moksleivių sveikatos stiprinimas. Kaunas: LKKA, 2006.

10. Kant S. Physical activity: A basic need for all. International Journal of Science and Research 2014; 3(1): 59-60.
11. Adaškevičienė E., Strazdienė N. Vaikų sveikatą stiprinančio fizinio aktyvumo ugdymas. Klaipėda: KU leidykla, 2013.

12. Global recommendations on physical activity for health. WHO: Geneva, 2010.

13. Steps to Health. A European framework to promote physical activity for health. Copenhagen: WHO Reagional Office for Europe, 2007.

\section{LIFESTYLE OF KLAIPEDA CITY POPULATION: FO- CUS ON PHYSICAL ACTIVITY}

\section{B. Strukčinskienė, I. Pačiauskaitė, S. Griškonis,} V. Strukčinskaitė, D. Stasiuvienė, I. Griškonytė

Key words: health, lifestyle, physical activity.

Summary

The survey on the lifestyle and physical activity was conducted in Klaipeda city. In the survey participated 1062 adult inhabitants of the Klaipeda city aged over 18 years ( 574 female and 488 male). The face-to-face interviews and quota sampling were applied. Chi-square test was used, and the significance level $\mathrm{p}<0.05$ was considered as statistically significant.

The study revealed that $46.4 \%$ of respondents think that the main source of information on healthy lifestyle for them is internet. Over the last year, only $7.3 \%$ of respondents improved their lifestyle for health promotion.

In most cases, Klaipeda citizens move by private cars (48\%) or by public transportation (43.5\%). Extremely small proportion of population ride bike $(1.3 \%)$ or walk by foot $(6.8 \%)$. About half of Klaipeda population (47.8\%) work at combined position (standing and sitting), one third (30.3\%) - in sitting position, one fifth $(20.5 \%)$ - at mobile work. Women work more mixed work (sitting and standing), and men -more mobile and hard physical work. Leisure physical activity of Klaipeda population remains insufficient. Only $13.4 \%$ respondents had taken leisure time physical activity for at least 30 minutes for four days per week. Even $45.5 \%$ of Klaipeda city inhabitants do not exercise. Only little proportion of both women and men had moderate physical activity at least for 4 days per week. One third of respondents self-reported that they have no time for physical activity or sport. Nearly half of respondents do sports at home. Women prefer to do sports at home, and men prefer to do sports at the sport club, gym, or stadium.

Correspondence to: birutedoctor@hotmail.com

Gauta 2014-10-06 